\title{
Hybrid Multivalent Jack Bean $\alpha$-Mannosidase Inhibitors: The First Example of Gold Nanoparticles Decorated with Deoxynojirimycin Inhitopes
}

\author{
Costanza Vanni ${ }^{1}$, Anne Bodlenner ${ }^{2, *} \mathbb{C}^{\circ}$, Marco Marradi ${ }^{1}{ }^{(}$, Jérémy P. Schneider ${ }^{2}$, Maria de los Angeles Ramirez ${ }^{3}$, \\ Sergio Moya ${ }^{3}$, Andrea Goti ${ }^{1,4}\left(\mathbb{D}\right.$, Francesca Cardona ${ }^{1,4}\left(\mathbb{D}\right.$, Philippe Compain ${ }^{2}$ and Camilla Matassini ${ }^{1,4, *(1)}$ \\ 1 Dipartimento di Chimica "Ugo Schiff”, Università di Firenze, Via della Lastruccia 3-13, \\ 50019 Sesto Fiorentino, Italy; costanza.vanni@unifi.it (C.V.); marco.marradi@unifi.it (M.M.); \\ andrea.goti@unifi.it (A.G.); francesca.cardona@unifi.it (F.C.) \\ 2 Laboratoire d'Innovation Moléculaire et Applications (LIMA), University of Strasbourg I University of \\ Haute-Alsace I CNRS (UMR 7042), Equipe de Synthèse Organique et Molécules Bioactives (SYBIO), ECPM, \\ 25 Rue Becquerel, 67000 Strasbourg, France; jeremy.schneider@live.fr (J.P.S.); \\ philippe.compain@unistra.fr (P.C.) \\ 3 Soft Matter Nanotechnology Lab, CIC biomaGUNE, Basque Research and Technology Alliance (BRTA), \\ Paseo Miramón 182, 20014 Donostia-San Sebastián, Gipuzkoa, Spain; aangie.ramirez@gmail.com (M.d.l.A.R.); \\ smoya@cicbiomagune.es (S.M.) \\ 4 Associated with LENS, Via N. Carrara 1, 50019 Sesto Fiorentino, Italy \\ * Correspondence: annebod@unistra.fr (A.B.); camilla.matassini@unifi.it (C.M.); Tel.: +33-36-8852684 (A.B.); \\ +39-055-457-3536 (C.M.)
}

Citation: Vanni, C.; Bodlenner, A.; Marradi, M.; Schneider, J.P.; Ramirez, M.d.1.A.; Moya, S.; Goti, A.; Cardona, F.; Compain, P.; Matassini, C. Hybrid Multivalent Jack Bean

$\alpha$-Mannosidase Inhibitors: The First Example of Gold Nanoparticles Decorated with Deoxynojirimycin Inhitopes. Molecules 2021, 26, 5864. https://doi.org/10.3390/ molecules26195864

Academic Editor: Keykavous Parang

Received: 2 September 2021

Accepted: 23 September 2021

Published: 27 September 2021

Publisher's Note: MDPI stays neutral with regard to jurisdictional claims in published maps and institutional affiliations.

Copyright: (c) 2021 by the authors. Licensee MDPI, Basel, Switzerland. This article is an open access article distributed under the terms and conditions of the Creative Commons Attribution (CC BY) license (https:// creativecommons.org/licenses/by/ $4.0 /)$.

\begin{abstract}
Among carbohydrate-processing enzymes, Jack bean $\alpha$-mannosidase (JB $\alpha$-man) is the glycosidase with the best responsiveness to the multivalent presentation of iminosugar inhitopes. We report, in this work, the preparation of water dispersible gold nanoparticles simultaneously coated with the iminosugar deoxynojirimycin (DNJ) inhitope and simple monosaccharides ( $\beta$-D-glucoor $\alpha$-D-mannosides). The display of DNJ at the gold surface has been modulated (i) by using an amphiphilic linker longer than the aliphatic chain used for the monosaccharides and (ii) by presenting the inhitope, not only in monomeric form, but also in a trimeric fashion through combination of a dendron approach with glyconanotechnology. The latter strategy resulted in a strong enhancement of the inhibitory activity towards JB $\alpha$-man, with a $K_{i}$ in the nanomolar range $\left(K_{i}=84 \mathrm{nM}\right)$, i.e., more than three orders of magnitude higher than the monovalent reference compound.
\end{abstract}

Keywords: multivalency; gold nanoparticles; iminosugars; enzyme inhibition; Jack bean $\alpha$-mannosidase

\section{Introduction}

More than ten years have passed since the first example of a trivalent deoxynojirimycin (DNJ) derivative, that displayed a small, but quantifiable, inhibitory multivalent effect for Jack bean $\alpha$-mannosidase (JB $\alpha$-man), was reported [1]. Until then, the multivalency concept was considered an exclusive prerogative of lectin-carbohydrate interactions, and its application to carbohydrate-processing enzymes was almost completely unexplored, being considered extremely challenging, from a practical standpoint, and theoretically arguable. The refutation of such speculations was apparent in 2010, when a fullerene-based 12-valent DNJ compound showed binding enhancements towards JB $\alpha$-man up to three orders of magnitude over the monovalent counterpart (inhibition constant $K_{i}=0.15 \mu \mathrm{M}$ vs. $\left.K_{i}=188 \mu \mathrm{M}\right)$ [2].

After that, a plethora of different scaffolds have been employed for the multimerization of DNJ, ranging from small polyols, $\beta$-cyclodextrins, porphyrins, calixarenes, and cyclopeptoids to more complex micellar self-assembled glycopeptides and polymeric dextrans [3-9]. 
The largest binding enhancement ever reported for an enzyme inhibitor, so far, was obtained with a cyclopeptoid core, decorated with 36 DNJ units [10], which showed a nanomolar inhibition value $\left(K_{i}=0.0011 \mu \mathrm{M}\right)$. More importantly, the outstanding multivalent effect observed with this 36 -valent cluster has been fully rationalized thanks to the recent achievement of the first high resolution crystal structure of its complex with $\mathrm{JB} \alpha$-man [11].

$\mathrm{JB} \alpha$-man enzyme $(220 \mathrm{kDa})$ is a homodimer $(\mathrm{LH})_{2}$ bearing two active sites. The crystal structure revealed the formation of a 2:1 JB $\alpha$-man:inhibitor complex, in which four DNJ inhitopes bind the four active sites of two homodimers [11]. The reported X-ray data of the $\mathrm{JB} \alpha$-man:inhibitor complex did not show any binding to secondary binding sites. Conversely, the observed multivalent effect was rationalized by invoking a chelate binding mode [11]. Through TEM studies, a different homodimer aggregation featuring an S-shape arrangement was proposed for $\mathrm{JB} \alpha$-man in the presence of a tetravalent pyrrolidine iminosugar 1,4-dideoxy-1,4-imino-D-arabinitol (DAB-1) inhibitor [12]. More generally, these data revealed that the binding modes of JB $\alpha$-man with iminosugar-based multivalent inhibitors strongly depend not only on the bioactive inhitope but also on the size and shape of the prepared multivalent architectures. Surprisingly, glyco-coated multivalent clusters also displayed some inhibition power on glycosidases instead of being hydrolyzed, as shown by the 12-valent mannosylated fullerene ( $K_{i}$ of $320 \mu \mathrm{M}$ for JB $\alpha$-man) [13], glyconanodiamonds ( $K_{i}$ between 222 and $517 \mu \mathrm{M}$ against JB $\alpha$-man) [14], and perglucosylated or permannosylated cyclodextrins (IC 50 of 32-132 $\mu \mathrm{M}$ against Saccharomyces cerevisiae $\alpha$-glucosidase) [15] probably arising from a lectin-like behavior in those clusters.

In this context, we envisaged that glyco-gold nanoparticles (AuGNPs), decorated with different loading and spatial presentation of DNJ inhitopes, could represent a versatile and useful molecular tool for further mechanistic studies.

AuGNPs, as prepared in our laboratory, are water-dispersible and biocompatible gold nanoparticles coated with a 3D polyvalent carbohydrate shell, having a globular shape, chemically defined composition, and exceptionally small core size (about $2 \mathrm{~nm}$ ) [16]. It is possible to simultaneously attach more than one kind of ligand onto the gold core (multifunctionality) and to modulate the ligand presentation on the metal surface in order to obtain multifunctional materials for application in nanomedicine (targeting, drug delivery, pathway inhibition, etc.) [17].

Despite the large number of different scaffolds employed for the DNJ multimerization, only three examples of nanoparticles (two inorganic [18,19] and one peptide-based [20]), decorated with this iminosugar, have been reported for different applications, to the best of our knowledge.

Some of us recently found that iminosugar-decorated AuGNPs retain inhibitory activity towards commercially available glycosidases [21]. We also reported that AuGNPs, decorated with DAB-1 iminosugar, were able to efficiently inhibit a therapeutically relevant enzyme [22]. Therein, a clickable iminosugar dendron approach [23] was combined with glyco-gold nanotechnology in order to obtain multivalent DAB-1 nanosystems with a denser iminosugar shell.

In the present work, we report our results, obtained applying this methodology to the preparation and characterization of AuGNPs decorated with simple monosaccharides, heterovalent DNJ-based ligands, either linear or dendritic (Figure 1), and their biological evaluation towards JB $\alpha$-man. 
(a) DNJ-coated AuGNP

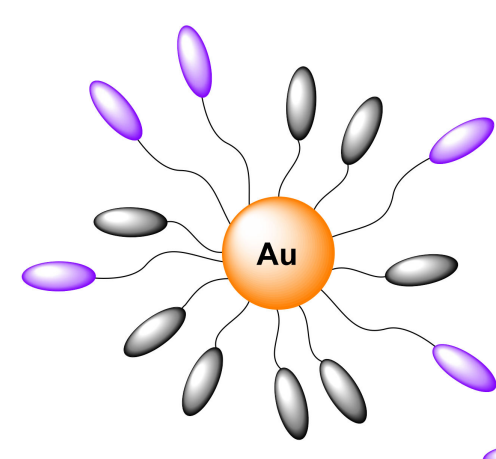

(b) DNJ dendron-coated AuGNP

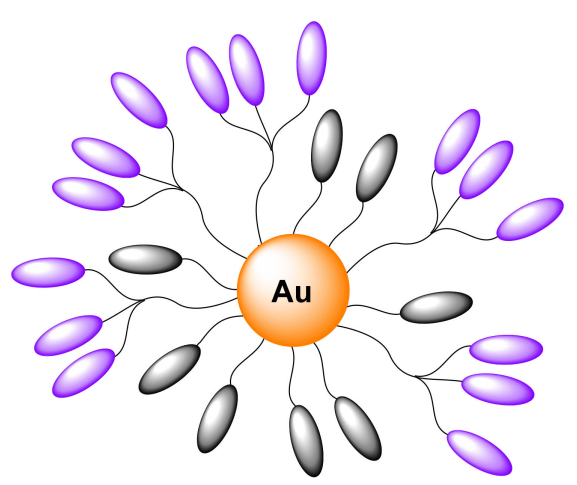

Figure 1. (a) Multivalent presentation of DNJ, using glyco-gold nanoparticles as scaffold and (b) the combination of glyco-gold nanotechnology with the iminosugar dendron approach.

\section{Results and Discussion}

\subsection{Preparation of Ligands and Gold Nanoparticles}

The gold nanoparticles (1-5) prepared in this work (Figure 2) are constituted by an approximately $2 \mathrm{~nm}$ gold core coated with two components: simple monosaccharides (D-glucose or D-mannose) and DNJ derivatives. We played on the nature of the inner monosaccharide and varied the density of DNJ heads on the periphery of the nanoparticles. Nanoparticles 6 and 7, in Figure 2, bearing 100\% monosaccharides with a short and linear five carbons $\left(C_{5}\right)$ aliphatic linker, were prepared as control systems. For AuGNPs 1-5, the carbohydrate moieties guarantee their water dispersibility, while the water soluble and flexible amphiphilic linker was designed to protrude the DNJ heads from the glyco-coated nanoparticle core. In addition, the $\mathrm{N}-\mathrm{C}_{6}$ aliphatic linker of the active component $\mathrm{DNJ}$ is taking part in the interaction with the catalytic site entry [11,24]. This strategy of ligand presentation was based on our previous experience with similar constructs $[21,22,25]$.

(a) DNJ-decorated Au-GNPs

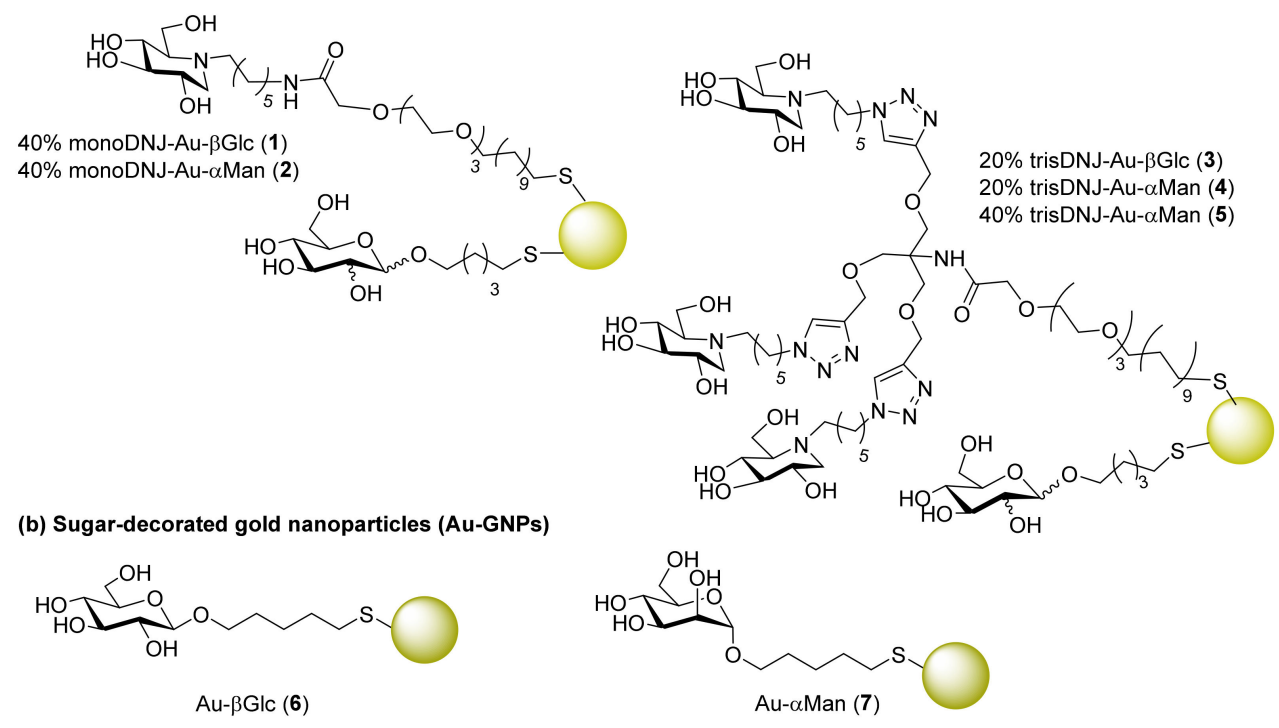

Figure 2. (a) Schematic representation of the multivalent glyco-gold nanoparticles coated with the iminosugar DNJ derivatives and monosaccharides ( $\beta$-D-glucose or $\alpha$-D-mannose derivatives) prepared in this work. (b) Nanoparticles coated with the monosaccharides (control systems). 
In particular, AuGNPs 6 and 7 were prepared employing, as exclusive components, 5 -mercaptopent-1-yl $\beta$-D-glucopyranoside $\left(\beta \mathrm{GlCC}_{5} \mathrm{SH}, 13\right)$ or 5 -mercaptopent-1-yl $\alpha$-Dmannopyranoside ( $\left.\alpha \mathrm{ManC}_{5} \mathrm{SH}, 14\right)$, following well established protocols [25]. AuGNPs $\mathbf{1}$ and $\mathbf{2}$ were prepared by employing the monovalent DNJ derivative $\mathbf{1 2}$ as the active component and $\mathbf{1 3}$ or $\mathbf{1 4}$, respectively, as the inner component (Scheme 1).

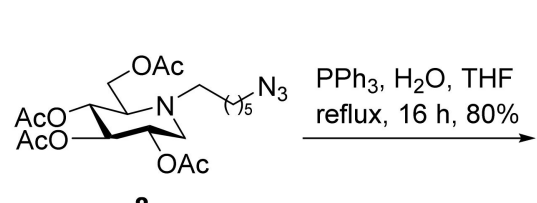

8

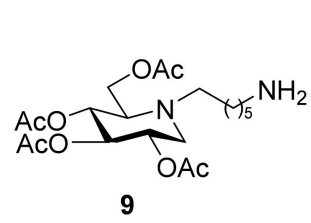

9

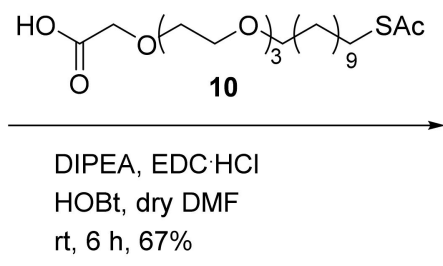

$\mathrm{MeONa}$

$\mathrm{CD}_{3} \mathrm{OD}$

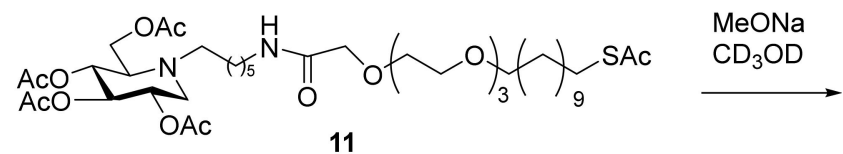

11

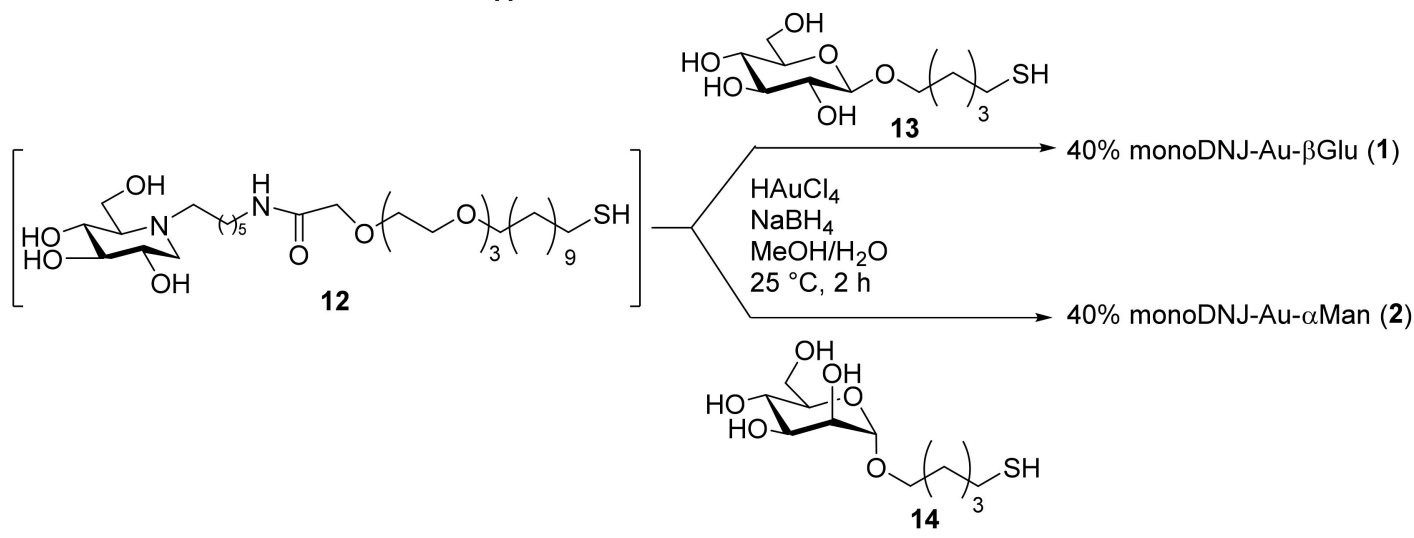

Scheme 1. Synthesis of the glyco-gold nanoparticles $\mathbf{1}$ and $\mathbf{2}$ decorated with the DNJ monovalent ligand 12.

The preparation of the monovalent DNJ derivative $\mathbf{1 2}$ is described in Scheme 1. The peracetylated azido-functionalized DNJ 8 [26] was reduced to the corresponding amino derivative 9 through a standard Staudinger reaction $\left(\mathrm{PPh}_{3}, \mathrm{H}_{2} \mathrm{O}\right.$, THF, reflux for $16 \mathrm{~h}$ ) in $80 \%$ yield. The same reaction performed with polymer-bound $\mathrm{PPh}_{3}[22,27]$, and refluxing in $\mathrm{THF} / \mathrm{H}_{2} \mathrm{O}$, required longer times and provided 9 in lower yields (48\%).

The aminoalkyl DNJ 9 was then coupled to the thiol-protected carboxylic acid 10, prepared, as reported in the literature [21], using 1-ethyl-3-(3-dimethylaminopropyl) carbodiimide (EDC) and 1-hydroxybenzotriazole (HOBt) in dry DMF. The amide $\mathbf{1 1}$ was obtained in $67 \%$ yield after purification by flash column chromatography (FCC). Removal of the acetyl groups of $\mathbf{1 1}$ was performed under Zemplén conditions (MeONa) but using $\mathrm{CD}_{3} \mathrm{OD}$, instead of $\mathrm{MeOH}$, as solvent to follow the reaction via ${ }^{1} \mathrm{H}$ NMR. Once compound 12 was formed, it was directly used for the next step, avoiding its oxidation to disulfide. AuGNPs 1 and 2 were prepared by mixing 12 with $\beta \mathrm{GlcC}_{5} \mathrm{SH}$ (13) or $\alpha \mathrm{ManC}_{5} \mathrm{SH}$ (14), respectively, in the appropriate ratio $(40 / 60)$ and then adding an $\mathrm{Au}(\mathrm{III})$ solution (the total amount of thiols being 3 equiv. with respect to gold) and the reducing agent $\mathrm{NaBH}_{4}$ in excess (Scheme 1). The proportion of the ligands on the gold surface was evaluated by integrating diagnostic signals in the ${ }^{1} \mathrm{H}$ NMR spectrum of the initial mixture and in the ${ }^{1} \mathrm{H}$ NMR spectrum of the supernatant after AuGNPs formation (see Supplementary Materials for ${ }^{1} \mathrm{H}$ NMR spectra). The $40 / 60$ active/inner component ratio allowed to preserve nanoparticle dispersibility in water [22]. After shaking for $2 \mathrm{~h}$ at room temperature, the supernatant was removed, and the nanoparticles were washed with methanol. The residue was dispersed in milliQ water, purified by dialysis, and freeze-dried. These nanoparticles were re-dispersed in water after the freeze-drying process, and no flocculation was 
observed even after several months. Full characterization with different techniques (see below) was carried out before enzymatic evaluation.

To further increase the DNJ loading onto AuGNPs, we combined this strategy with the dendron approach by preparing the trivalent DNJ derivative 18 (Scheme 2). The peracetylated azido-functionalized DNJ 8 was first reacted with the trialkyne 15 [28] to afford the dendron 16 in $85 \%$ yield through copper (I) catalyzed azide alkyne cycloaddition (CuAAC) reaction [29-31]. Subsequently, introduction of the linker was achieved by coupling the carboxylic acid $\mathbf{1 0}$ with $\mathbf{1 6}$ in the presence of 3-(diethoxyphosphoryloxy)1,2,3-benzotriazin-4(3H)-one (DEPBT) as coupling agent affording the final ligand $\mathbf{1 7}$ in an excellent $94 \%$ yield. In analogy with the incorporation of the monovalent ligand 12 onto AuGNPs, trivalent thiol 18 was generated in situ, and its density on the nanoparticles was modulated with $\beta$ GlcC5SH (13) (to yield AuGNPs 3) or $\alpha$ ManC5SH (14) (to yield AuGNPs 4 and 5), as described above. The mannose-based AuGNPs 4 and 5 shared the same inner component but in different percentages ( $80 \%$ in $4,60 \%$ in 5$)$.
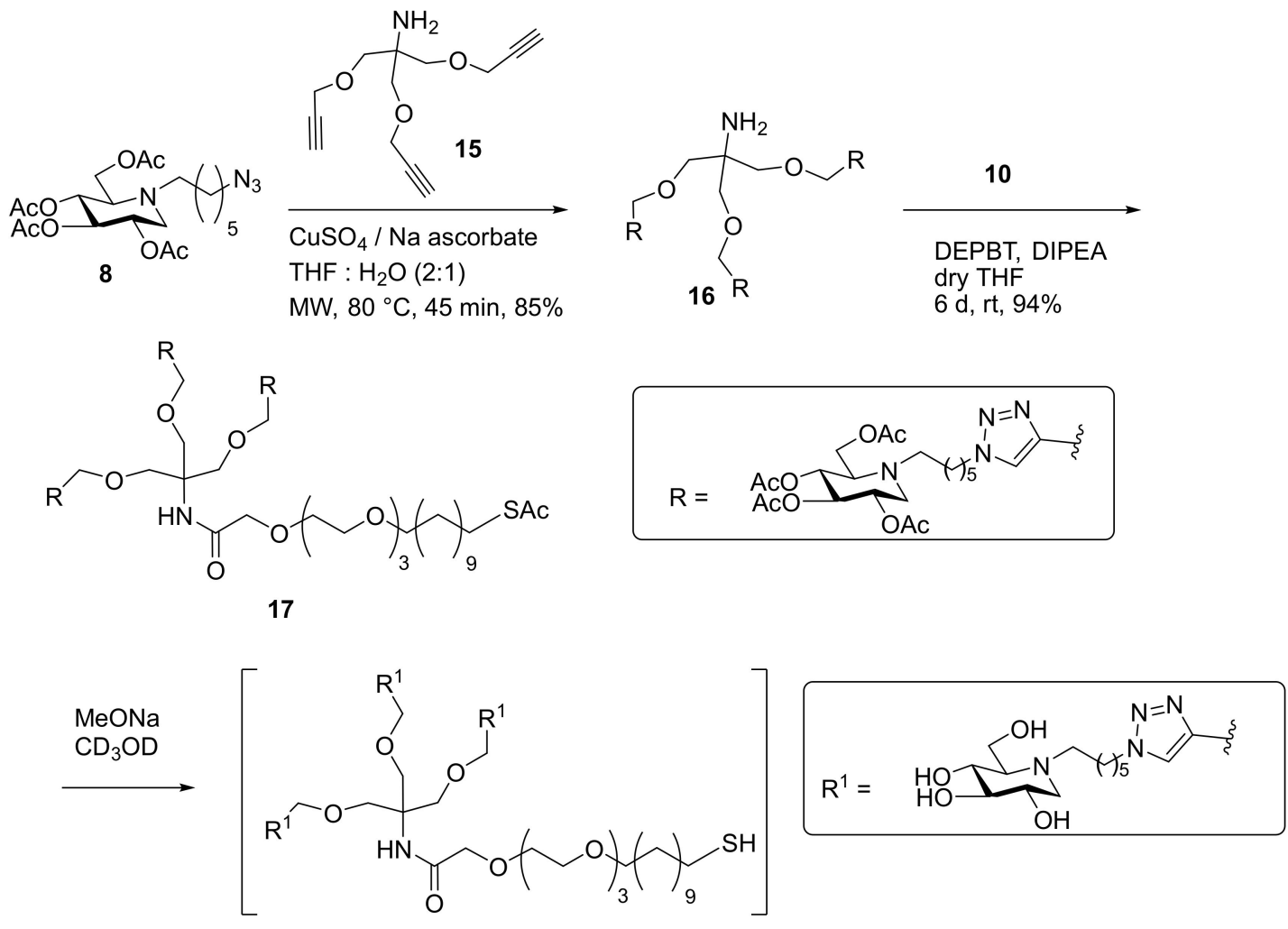

18

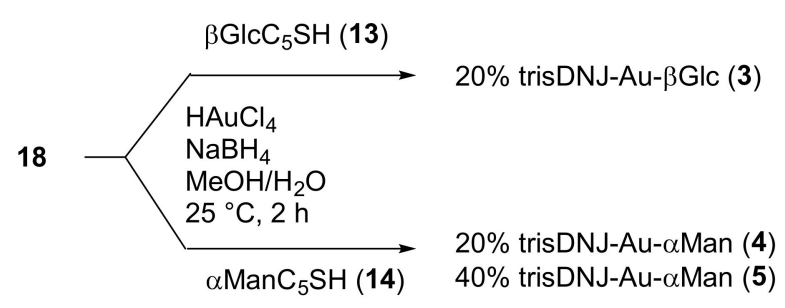

Scheme 2. Synthesis of the trivalent ligand 18 and preparation of AuGNPs 3-5.

AuGNPs 1-5 were subjected to quantitative ${ }^{1} \mathrm{H}$ NMR (qNMR) analysis in $\mathrm{D}_{2} \mathrm{O}$ with 3-(trimethylsilyl)propionic-2,2,3,3- $d_{4}$ acid (TSP- $\mathrm{d}_{4}$ ) as an internal standard, following established protocols $[21,32,33]$. As an example, Figure 3a shows the qNMR for AuGNP 3. In this way, it was possible to quantify the DNJ amount on the nanoparticle by integration of a diagnostic signal (see Supplementary Materials and Table S1) with respect to the 
internal standard. An average gold core size in 1.6-2.1 nm range was determined by TEM imaging for the AuGNPs (Figure 3c,d) [25,34]. This size was also confirmed by UV-Vis spectra, which did not show an absorption maximum at around $520 \mathrm{~nm}$, typical of gold nanoparticles with a bigger core diameter [35] (Figure 3b).

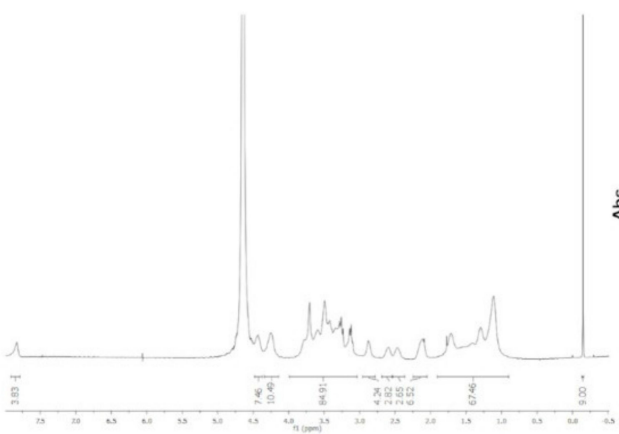

(a) Quantitative 'H-NMR

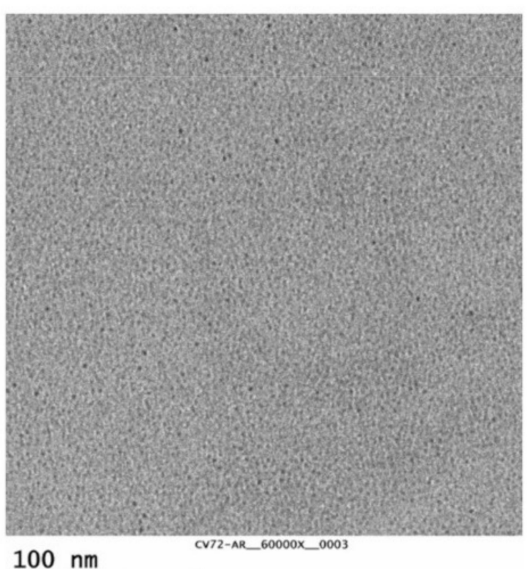

(c) TEM

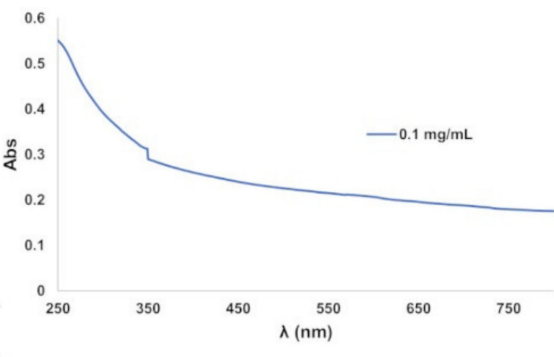

(b) UV-Vis

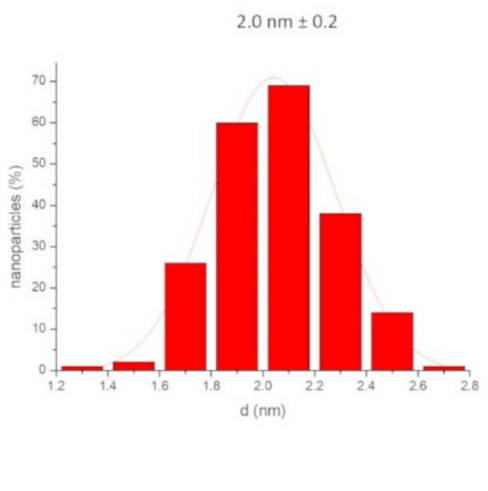

(d) Distribution of AuGNP diameter

Figure 3. Characterization of AuGNP 3 (20\% trisDNJ-Au- $\beta$ Glc): (a) quantitative ${ }^{1} \mathrm{H} N M R\left(D_{2} \mathrm{O}\right)$ spectrum (400 MHz); (b) UV/Vis spectrum; (c) TEM micrograph in $\mathrm{H}_{2} \mathrm{O}$; (d) size-distribution histogram, obtained by measuring 300 nanoparticles (average diameter $2.0 \pm 0.2 \mathrm{~nm}$ ).

\subsection{Biological Evaluation}

The DNJ-coated AuGNPs 1-5 were evaluated against Jack bean $\alpha$-mannosidase (JB $\alpha$ man), the glycosidase which showed the largest response to multivalent inhibitor presentation to date [3-9]. The inhibition mode and constants $\left(K_{i}\right)$ were obtained from Dixon or Lineweaver Burk plots for a scale of inhibitor concentrations reflecting the DNJ concentration directly. The inhibition potency, relative to the corresponding monovalent reference 19 [36] (Figure 4), directly gives the relative potency per inhitope (rpn) (Table 1).

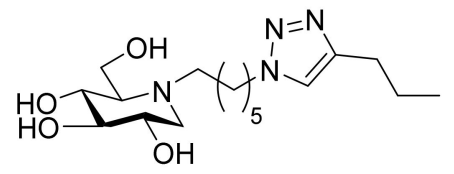

19

$$
\left(\mathrm{K}_{i}=322 \mu \mathrm{M}\right)^{35}
$$

Figure 4. DNJ derivative chosen as the monovalent reference to evaluate the relative potency of the AuGNPs synthesized in this work. 
Table 1. Inhibitory activity of AuGNPs 1-7 towards Jack bean $\alpha$-mannosidase (JB $\alpha$-man).

\begin{tabular}{|c|c|c|c|}
\hline AuGNP & $\begin{array}{c}\text { DNJ Conc. }(\mu \mathrm{M}) \\
\text { in } 2 \mathrm{mg} \mathrm{mL}^{-1} \mathrm{AuGNP} 1\end{array}$ & $K_{i}(\mu \mathrm{M})^{2}$ & $r p n^{3}$ \\
\hline 1 & 413 & $16 \pm 2$ & 20 \\
\hline 2 & 467 & $8 \pm 2$ & 40 \\
\hline 3 & 567 & $0.198 \pm 0.060$ & 1626 \\
\hline 4 & 450 & $0.175 \pm 0.171$ & 1840 \\
\hline 5 & 503 & $0.084 \pm 0.066$ & 3833 \\
\hline 6 & 0 & n.i. ${ }^{4}$ & - \\
\hline 7 & 0 & n.i. ${ }^{4}$ & - \\
\hline
\end{tabular}

${ }^{1}$ Estimated by qNMR. ${ }^{2}$ The inhibition constant unit directly reflects the concentration of DNJ and not the concentration of nanoparticles. ${ }^{3}$ Relative potency per DNJ unit, with respect to the monovalent reference 19; $r p n=K_{i}$ (monovalent reference 19) $/ K_{i}$ (DNJ in AuGNP 1-5). ${ }^{4}$ n.i. $=$ no inhibition at $0.5 \mathrm{mg} \mathrm{mL}^{-1}$.

The whole set of newly prepared heterovalent AuGNPs $\mathbf{1 - 5}$ showed good to excellent inhibitory activity towards JB $\alpha$-man, with $K_{i}$ values in the low micromolar range to the nanomolar one. All behaved as competitive inhibitors (see Supplementary Materials). Conversely, $\beta$-D-gluco- and $\alpha$-D-mannoside decorated AuGNPs 6 and 7 did not inhibit the enzyme at $0.5 \mathrm{mg} \mathrm{mL}^{-1}$ (This concentration was a good compromise to allow spectrophotometric measurements due to the brown color of AuGNP solutions. The 12-valent mannosylated fullerene from Vincent and Nierengarten et al. (see ref [13]) was active at the hundreds of $\mu \mathrm{M})$. However, trimerization of DNJ at the gold surface had a major impact: it strongly enhances the affinity towards JB $\alpha$-man (3 vs. 1, 4 vs. 2, Table 1 ), with the affinity enhancement per inhitope increasing up to 1840 for AuGNP 4. A further enhancement of the inhibitory properties was reached upon increasing the loading of the trivalent DNJ derivative 18 onto the gold surface from $20 \%$ to $40 \%$, with a $K_{i}$ at $84 \mathrm{nM}$ and an $r p n$ value of 3833 observed for AuGNP 5 (Table 1).

Noticeably, the dendron strategy is a double-edged sword. On the one hand, the intrinsic hindrance of the iminosugar tripod seems to prevent loading as high as linear arms (It is worth noting that for a same percentage loading of D-mannose of $60 \%$, the DNJ concentration on AuGNP 5 is not 3 times higher than that of AuGNP 2, suggesting that the total loading on the particle is lower than for AuGNP 2. However, the ratio between iminosugar DNJ derivatives and monosaccharides still reflects the composition of the preparation mixture, as attested by ${ }^{1} \mathrm{H}-\mathrm{NMR}$ spectra recorded before and after (supernatant) the formation of the AuGNPs (see Supplementary Materials)). On the second hand, although the DNJ concentration is almost identical (503 vs. 467 for AuGNP 2 and 5), the inhibition constant of AuGNP 5 is more than 100 times better (Table 1 and Table S1). Despite this lower coating, the multivalent effect, as judged by the rpn, is remarkably increased by two orders of magnitude. The spatial distribution of DNJ at the AuGNP 5, as obtained through the dendron strategy, is highly beneficial to the enzymatic affinity. AuGNPs thus represent an opportunity to compare multivalent systems, having similar concentrations in DNJ inhitopes, but with different local densities. In DNJ dendron-coated AuGNPs, the higher local concentration may favor the bind-and-recapture of the reversible inhibitor heads.

\section{Materials and Methods}

\subsection{General Experimental Procedures for the Syntheses}

Commercial reagents were used as received. All reactions were carried out under magnetic stirring and monitored by TLC on $0.25 \mathrm{~mm}$ silica gel plates (Merck F254). Column chromatographies were carried out on Silica Gel $60(32-63 \mu \mathrm{m})$ or on silica gel (230-400 mesh, Merck, Darmstadt, Germany). Yields refer to spectroscopically and analytically pure compounds unless otherwise stated. ${ }^{1} \mathrm{H}$ NMR spectra were recorded on a Varian Gemini $200 \mathrm{MHz}$, a Varian Mercury $400 \mathrm{MHz}$, or on a Varian INOVA $400 \mathrm{MHz}$ instrument at $25^{\circ} \mathrm{C}$. Additionally, ${ }^{13} \mathrm{C}$ NMR spectra were recorded on a Varian Gemini $200 \mathrm{MHz}$ or on a Varian Mercury $400 \mathrm{MHz}$ instrument. Chemical shifts are reported relative to $\mathrm{CDCl}_{3}\left({ }^{13} \mathrm{C}\right.$ : 
$\delta=77.0 \mathrm{ppm})$, or to $\mathrm{CD}_{3} \mathrm{OD}\left({ }^{13} \mathrm{C}: \delta=49.0 \mathrm{ppm}\right)$. The following abbreviations were used to designate multiplicities: $\mathrm{s}=$ singlet, $\mathrm{d}=$ doublet, $\mathrm{t}=$ triplet, $\mathrm{m}=$ multiplet, $\mathrm{br}=$ broad, and $\mathrm{dd}=$ double-doublet. Integrals are in accordance with assignments, coupling constants are given in Hz. For detailed peak assignments, 2D spectra were measured (COSY, HSQC). IR spectra were recorded with a IRAffinity-1S SHIMADZU system spectrophotometer. ESI-MS spectra were recorded with a Thermo Scientific ${ }^{\mathrm{TM}}$ LCQ fleet ion trap mass spectrometer. Elemental analyses were performed with a Thermo Finnigan FLASH EA 1112 CHN/S analyzer. Optical rotation measurements were performed on a JASCO DIP-370 polarimeter. TEM analysis was performed with a LaB6-TEM of type JEOL JEM-1400PLUS (40 kV-120 kV, $\mathrm{HC}$ pole piece) equipped with a GATAN US1000 CCD camera ( $2 \mathrm{k} \times 2 \mathrm{k})$.

\subsubsection{Synthesis of Monovalent DNJ Derivative 9}

To a solution of $8(36 \mathrm{mg}, 79 \mu \mathrm{mol})$ in $1.5 \mathrm{~mL}$ of THF $4.6 \mathrm{~mL}$ and $3 \mu \mathrm{L}$ of $\mathrm{H}_{2} \mathrm{O}(145 \mu \mathrm{mol})$, $\mathrm{PPh}_{3}(25 \mathrm{mg}, 87 \mu \mathrm{mol})$ was added. The reaction mixture was then refluxed for $16 \mathrm{~h}$, until a TLC analysis $\left(\mathrm{CH}_{2} \mathrm{Cl}_{2} / \mathrm{MeOH} 10: 1\right)$ showed the disappereance of the starting material $(\mathrm{Rf}=0.91)$ and the formation of a new product $(R \mathrm{f}=0.10)$. The solvent was removed under reduced pressure and the crude was purified by FCC (from $\mathrm{CH}_{2} \mathrm{Cl}_{2} / \mathrm{MeOH} 10: 1$ to $\mathrm{CH}_{2} \mathrm{Cl}_{2} / \mathrm{MeOH} / \mathrm{NH}_{3}$ 5:1:0.2) affording pure $9\left(25 \mathrm{mg}, 58.1 \mu \mathrm{mol}, \mathrm{Rf}=0.10\right.$ in $\left.\mathrm{CH}_{2} \mathrm{Cl}_{2} / \mathrm{MeOH} 10: 1\right)$ as a colourless oil in $80 \%$ yield. $[\alpha]_{\mathrm{D}}^{22}=4.75\left(\mathrm{c}=0.59\right.$ in $\left.\mathrm{CHCl}_{3}\right) ;{ }^{1} \mathrm{H}-\mathrm{NMR}\left(400 \mathrm{MHz}, \mathrm{CDCl}_{3}\right): \delta=5.05(\mathrm{dt}, J=17.1$, $9.2 \mathrm{~Hz}, 2 \mathrm{H}, \mathrm{H}-3, \mathrm{H}-4), 4.94$ (td, $J=10.0,5.0 \mathrm{~Hz}, 1 \mathrm{H}, \mathrm{H}-2), 4.19-4.09$ (m, 2H, H-6), 3.18 (dd, $J=11.5,5.1 \mathrm{~Hz}, 1 \mathrm{H}, \mathrm{Ha}-1), 2.75-2.68\left(\mathrm{~m}, 1 \mathrm{H}, \mathrm{Ha}-1^{\prime}\right), 2.62(\mathrm{dt}, J=11.6,2.5 \mathrm{~Hz}, 1 \mathrm{H}, \mathrm{H}-5), 2.57-2.50$ $\left(\mathrm{m}, 1 \mathrm{H}, \mathrm{Hb}-1^{\prime}\right), 2.43\left(\mathrm{bs}, 2 \mathrm{H}, \mathrm{H}-6^{\prime}\right), 2.30(\mathrm{t}, J=10.5 \mathrm{~Hz}, 1 \mathrm{H}, \mathrm{Hb}-1), 2.06\left(\mathrm{~s}, 3 \mathrm{H}, \mathrm{OCH}_{3}\right), 2.01(\mathrm{~s}, 6 \mathrm{H}$, $\left.\mathrm{OCH}_{3}\right), 2.00\left(\mathrm{~s}, 3 \mathrm{H}, \mathrm{OCH}_{3}\right), 1.48-1.22\left(\mathrm{~m}, 8 \mathrm{H}, \mathrm{H}-2^{\prime}, \mathrm{H}-3^{\prime}, \mathrm{H}-4^{\prime}, \mathrm{H}-5^{\prime}\right)$ ppm; ${ }^{13} \mathrm{C}-\mathrm{NMR}(100 \mathrm{MHz}$, $\left.\mathrm{CDCl}_{3}\right): \delta=171.0-169.9\left(4 \mathrm{C}, \mathrm{OCOCH}_{3}\right), 74.8(\mathrm{C}-2), 69.7(\mathrm{C}-4), 69.6$ (C-3), 61.7 (C-5), $59.7(\mathrm{C}-6)$, $53.0(\mathrm{C}-1), 51.8\left(\mathrm{C}-1^{\prime}\right), 27.1-26.8\left(4 \mathrm{C}\right.$, from $\mathrm{C}^{\prime}$ to $\left.\mathrm{C}^{\prime}\right), 24.9\left(\mathrm{C}-6^{\prime}\right), 21.0-20.8\left(4 \mathrm{C}, \mathrm{COCH}_{3}\right) \mathrm{ppm}$; MS (ESI): $m / z 431.04\left(100, \mathrm{H}^{+}\right) . \operatorname{IR}\left(\mathrm{CDCl}_{3}\right): \widetilde{v}=2935,2860,2255,1744,1664,1601,1508,1369$, $1234,1061,1032 \mathrm{~cm}^{-1}$. Elemental analysis (\%) for $\mathrm{C}_{20} \mathrm{H}_{34} \mathrm{~N}_{2} \mathrm{O}_{8}$ (430.49): calcd C, 55.80; H, 7.96; N, 6.51; found: C, 56.34; H, 7.57; N, 6.90.

\subsubsection{Synthesis of Monovalent DNJ Based Ligand 11}

A solution of EDC $\cdot \mathrm{HCl}$ (1-Ethyl-3-(3-dimethylaminopropyl) carbodimide hydrochloride $(18.2 \mathrm{mg}, 95 \mu \mathrm{mol})$, 1-hydroxybenzotriazole (HOBt, $11.7 \mathrm{mg}, 87 \mu \mathrm{mol})$, and 10 (25.9 mg, $59 \mu \mathrm{mol})$ in dry DMF $(0.2 \mathrm{~mL})$ was left stirring for $10 \mathrm{~min}$. and then added to a solution of DNJ derivative $9(17.0 \mathrm{mg}, 40 \mu \mathrm{mol})$ and $N, N$-diisopropylethylamine $(19 \mu \mathrm{L}, 107 \mu \mathrm{mol})$ in DMF $(0.9 \mathrm{~mL})$. The reaction mixture was left stirring at room temperature, under nitrogen atmosphere, for $6 \mathrm{~h}$, then diluted with AcOEt $(10 \mathrm{~mL})$ and washed with $\mathrm{H}_{2} \mathrm{O}(2 \times 3 \mathrm{~mL})$. The organic layer was then washed with a saturated solution of $\mathrm{NaHCO}_{3}(1 \times 3 \mathrm{~mL})$ and brine $(1 \times 4 \mathrm{~mL})$, dried over anhydrous $\mathrm{Na}_{2} \mathrm{SO}_{4}$ and concentrated under vacuum. The crude was purified by column chromatography (DCM/MeOH from 30:1 to 10:1) affording $22 \mathrm{mg}$ of 11 (26 $\mu \mathrm{mol}, 67 \%$ yield). $R \mathrm{f}=0.32\left(\mathrm{CH}_{2} \mathrm{Cl}_{2} / \mathrm{MeOH} 10: 1\right) .[\alpha]_{\mathrm{D}}^{26}=3.33(\mathrm{c}=0.69 \mathrm{in}$ $\left.\mathrm{CHCl}_{3}\right) .{ }^{1} \mathrm{H}-\mathrm{NMR}\left(400 \mathrm{MHz}, \mathrm{CDCl}_{3}\right): \delta=5.06(\mathrm{dt}, J=9.2,2.8 \mathrm{~Hz}, 2 \mathrm{H}, \mathrm{H}-3, \mathrm{H}-4), 4.99-4.92$ (m, 1H, H-2), 4.17-4.13 (m, 2H, H-6), $3.98\left(\mathrm{~s}, 2 \mathrm{H}, \mathrm{CH}_{2}=\mathrm{CO}\right), 3.69-3.56(\mathrm{~m}, 12 \mathrm{H}), 3.44(\mathrm{t}$, $J=6.8 \mathrm{~Hz}, 2 \mathrm{H}), 3.29-3.16\left(\mathrm{~m}, 3 \mathrm{H}, \mathrm{H}-6^{\prime}, \mathrm{Ha}-1\right), 2.85$ (t, $\left.J=3.6 \mathrm{~Hz}, 2 \mathrm{H}, \mathrm{CH}_{2} \mathrm{SAc}\right), 2.77-2.69$ (m, $\left.1 \mathrm{H}, \mathrm{Ha}^{\prime} \mathrm{1}^{\prime}\right), 2.64-2.61$ (m, 1H, H-5), 2.58-2.52 (m, 1H, Hb-1'), 2.32 (bs, 4H, SCOCH, $\left.\mathrm{Hb}-1\right)$, $2.08\left(\mathrm{~s}, 3 \mathrm{H}, \mathrm{OCH}_{3}\right), 2.02\left(\mathrm{~s}, 6 \mathrm{H}, \mathrm{OCH}_{3}\right), 2.01\left(\mathrm{~s}, 3 \mathrm{H}, \mathrm{OCH}_{3}\right), 1.59-1.45(\mathrm{~m}, 4 \mathrm{H}), 1.36-1.25(\mathrm{~m}$, 22H) ppm; ${ }^{13} \mathrm{C}-\mathrm{NMR}\left(50 \mathrm{MHz} \mathrm{CDCl}_{3}\right): \delta=196.0\left(\mathrm{SCOCH}_{3}\right), 170.8-170.0\left(4 \mathrm{C},-\mathrm{OCOCH}_{3}\right)$, 169.7 (CONH), 74.7 (C-2), 71.6-70.0 (8C), 69.5 (C-4), 69.4 (d, C-3), 61.5 (C-5), 59.5 (C-6), $52.9(\mathrm{C}-1), 51.7\left(\mathrm{C}-1^{\prime}\right), 38.7\left(\mathrm{C}-6^{\prime}\right), 30.6\left(\mathrm{SCOCH}_{3}\right), 29.6-28.8(11 \mathrm{C}), 26.9-26.1\left(3 \mathrm{C}, \mathrm{C}-2^{\prime}, \mathrm{C}-\right.$ $\left.3^{\prime}, \mathrm{C}-4^{\prime}\right), 20.8-20.6\left(4 \mathrm{C}, \mathrm{COCH}_{3}\right)$ ppm; MS (ESI): $m / z 871.35\left(100, \mathrm{M}+\mathrm{Na}^{+}\right)$. IR $\left(\mathrm{CDCl}_{3}\right)$ : $\tilde{v}=3005,2929,2856,1744,1673,1540,1466,1370,1237,1107,1033 \mathrm{~cm}^{-1}$; Elemental analysis (\%) for $\mathrm{C}_{41} \mathrm{H}_{72} \mathrm{~N}_{2} \mathrm{O}_{14} \mathrm{~S}$ (849.08): calcd C, 58.00; H, 8.55; N, 3.30; found: C, 56.44; H, 7.90; $\mathrm{N}, 2.39$. 


\subsubsection{Synthesis of Trivalent DNJ Derivative $\mathbf{1 6}$}

To a solution of $8(63 \mathrm{mg}, 138 \mu \mathrm{mol})$ in $3 \mathrm{~mL}$ of THF $/ \mathrm{H}_{2} \mathrm{O}=2: 1 \mathrm{CuSO}_{4}(2.1 \mathrm{mg}$, $13 \mu \mathrm{mol})$, sodium ascorbate $(5 \mathrm{mg}, 25 \mu \mathrm{mol})$ and 15 [28] $(9.9 \mathrm{mg}, 42 \mu \mathrm{mol})$ were added. The reaction mixture was stirred in microwave at $80^{\circ} \mathrm{C}$ for $45 \mathrm{~min}$, until a TLC analysis $\left(\mathrm{CH}_{2} \mathrm{Cl}_{2} / \mathrm{MeOH} 10: 1\right)$ showed the disappearance of the starting material $(R \mathrm{f}=0.46)$ and the formation of a new product $(R \mathrm{f}=0.00)$. The solvent was removed under reduced pressure and the crude was purified by FCC $\left(\mathrm{CH}_{2} \mathrm{Cl}_{2} / \mathrm{MeOH} / \mathrm{NH}_{3}\right.$ from 30:1 to 5: 1: 0.1) affording pure $16\left(57 \mathrm{mg}, 35.4 \mu \mathrm{mol}, \mathrm{Rf}=0.33\right.$ in $\mathrm{CH}_{2} \mathrm{Cl}_{2} / \mathrm{MeOH} / \mathrm{NH}_{3}$ 10:1:0.1) as a pale yellow oil, in $85 \%$ yield. $[\alpha]_{\mathrm{D}}^{22}=7.47\left(\mathrm{c}=0.91\right.$ in $\left.\mathrm{CHCl}_{3}\right) .{ }^{1} \mathrm{H}-\mathrm{NMR}\left(400 \mathrm{MHz}, \mathrm{CDCl}_{3}\right)$ : $\delta=7.56(\mathrm{br} \mathrm{s}, 3 \mathrm{H}$, triazole), 5.09-5.01 (m, 6H, H-3, H-4), 4.97-4.91 (m, 3H, H-2), $4.60(\mathrm{~s}$, $\left.6 \mathrm{H}, \mathrm{H}-7^{\prime}\right), 4.34\left(\mathrm{t}, J=7.2 \mathrm{~Hz}, 6 \mathrm{H}, \mathrm{H}-6^{\prime}\right), 4.18-4.10(\mathrm{~m}, 6 \mathrm{H}, \mathrm{H}-6), 3.44\left(\mathrm{~s}, 6 \mathrm{H}, \mathrm{H}-8^{\prime}\right), 3.18(\mathrm{dd}$, $J=11.4,5.0 \mathrm{~Hz}, 3 \mathrm{H}, \mathrm{Ha}-1), 2.76-2.69$ (m, 3H, Ha-1'), 2.63-2.60 (m, 3H, H-5), 2.56-2.50 (m, $\left.3 \mathrm{H}, \mathrm{Hb}-1^{\prime}\right), 2.29(\mathrm{t}, J=10.8 \mathrm{~Hz}, 3 \mathrm{H}, \mathrm{Hb}-1), 2.07\left(\mathrm{~s}, 9 \mathrm{H}, \mathrm{OCH}_{3}\right), 2.02-2.01\left(\mathrm{~m}, 27 \mathrm{H}, \mathrm{OCH}_{3}\right)$, 1.94-1.84 (m, 6H, H-5'), 1.45-1.25 (m, 18H, H-2', H-3' $\left.\mathrm{H}^{\prime} 4^{\prime}\right)$ ppm; ${ }^{13} \mathrm{C}-\mathrm{NMR}(100 \mathrm{MHz}$, $\left.\mathrm{CDCl}_{3}\right): \delta=170.9-169.9\left(12 \mathrm{C}, \mathrm{OCOCH}_{3}\right), 145.2(3 \mathrm{C}$, triazole), 122.5 (3C, triazole), $74.8(3 \mathrm{C}$, C-2), 72.4 (3C, C-8'), 69.7 (3C, C-4), 69.6 (3C, C-3), 65.2 (3C, C-7'), 61.9 (3C, C-5), 59.8 (3C, C-6), $\left.56.3\left(\mathrm{NH}_{2} \mathrm{C}\left(\mathrm{CH}_{2} \mathrm{O}-\right)_{3}\right), 53.0(3 \mathrm{C}, \mathrm{C}-1), \mathrm{NH}_{2} \mathrm{C}\left(\mathrm{CH}_{2} \mathrm{O}-\right)_{3}\right), 51.7\left(3 \mathrm{C}, \mathrm{C}-1^{\prime}\right), 50.3\left(3 \mathrm{C}, \mathrm{C}-6^{\prime}\right)$, $30.4\left(3 \mathrm{C}, \mathrm{C}-5^{\prime}\right), 26.8\left(3 \mathrm{C}, \mathrm{C}-2^{\prime}\right), 26.6\left(3 \mathrm{C}, \mathrm{C}-3^{\prime}\right), 25.1\left(3 \mathrm{C}, \mathrm{C}-4^{\prime}\right), 21.0-20.8\left(12 \mathrm{C}, \mathrm{COCH}_{3}\right)$ ppm; MS (ESI): $m / z 1626.58\left(100, \mathrm{Na}^{+}\right)$; IR (CDCl3): $\tilde{v}=3690,3606,2937,2862,2257,1745$, $1602,1438,1370,1234,1097,1052,1032 \mathrm{~cm}^{-1}$. Elemental analysis (\%) for $\mathrm{C}_{73} \mathrm{H}_{113} \mathrm{~N}_{13} \mathrm{O}_{27}$ (1604.75): calcd C, 54.64; H, 7.10; N, 11.35; found: C, 54.60; H, 7.35; N, 10.37.

\subsubsection{Synthesis of Trivalent DNJ Based Ligand $\mathbf{1 7}$}

To a solution of compound $\mathbf{1 6}(56.8 \mathrm{mg}, 35.4 \mu \mathrm{mol})$ in dry THF $(570 \mu \mathrm{L})$ at $0{ }^{\circ} \mathrm{C}$, 3-(diethoxyphosphoryloxy)-1,2,3-benzotriazin-4(3H)-one (DEPBT $21.2 \mathrm{mg}, 70.8 \mu \mathrm{mol}$ ) and $\mathrm{N}, \mathrm{N}$-diisopropylethylamine (DIPEA $12.0 \mu \mathrm{L}, 70.8 \mu \mathrm{mol}$ ) were added. The mixture was stirred at $25^{\circ} \mathrm{C}$ for $15 \mathrm{~min}$ under a nitrogen atmosphere, then a solution of $\mathbf{1 0}(30.0 \mathrm{mg}$, $21.6 \mu \mathrm{mol})$ in dry THF $(225 \mu \mathrm{L})$ was added and the reaction mixture was stirred at room temperature for 6 days, until a TLC analysis $\left(\mathrm{CH}_{2} \mathrm{Cl}_{2} / \mathrm{MeOH}\right.$ 6:1) showed the formation of a new product $(R \mathrm{f}=0.7)$. The reaction mixture was diluted with AcOEt $(5 \mathrm{~mL})$, washed with $\mathrm{NH}_{4} \mathrm{Cl}(2 \times 3 \mathrm{~mL}), \mathrm{NaHCO}_{3}(2 \times 3 \mathrm{~mL})$ and $\mathrm{H}_{2} \mathrm{O}(2 \times 3 \mathrm{~mL})$, dried over anhydrous $\mathrm{Na}_{2} \mathrm{SO}_{4}$ and concentrated under vacuum. Purification through gradient column chromatography $\left(\mathrm{CH}_{2} \mathrm{Cl}_{2} / \mathrm{MeOH}\right.$ from 20:1 to 10:1) afforded pure $17(61 \mathrm{mg}, 30.1 \mu \mathrm{mol})$ as a yellow oil, in 94\% yield. $[\alpha]_{\mathrm{D}}^{18}=5.29\left(\mathrm{c}=0.87\right.$ in $\left.\mathrm{CHCl}_{3}\right) .{ }^{1} \mathrm{H}-\mathrm{NMR}\left(400 \mathrm{MHz}, \mathrm{CDCl}_{3}\right): \delta=7.54(\mathrm{br} \mathrm{s}, 3 \mathrm{H}$, triazole), $6.81(\mathrm{~s}, 1 \mathrm{H}, \mathrm{CONH}), 5.06-4.98(\mathrm{~m}, 6 \mathrm{H}, \mathrm{H}-3, \mathrm{H}-4), 4.94-4.88(\mathrm{~m}, 3 \mathrm{H}, \mathrm{H}-2), 4.57(\mathrm{~s}$, $\left.6 \mathrm{H}, \mathrm{H}-7^{\prime}\right), 4.31\left(\mathrm{t}, J=7.2 \mathrm{~Hz}, 6 \mathrm{H}, \mathrm{H}-6^{\prime}\right), 4.15-4.07(\mathrm{~m}, 6 \mathrm{H}, \mathrm{H}-6), 3.84(\mathrm{~s}, 2 \mathrm{H}), 3.77(\mathrm{~s}, 6 \mathrm{H}$, H-8 $), 3.63-3.51(\mathrm{~m}, 12 \mathrm{H}), 3.39(\mathrm{t}, J=6.8 \mathrm{~Hz}, 2 \mathrm{H}), 3.15(\mathrm{dd}, J=11.5,5.1 \mathrm{~Hz}, 3 \mathrm{H}, \mathrm{Ha}-1)$, $2.82(\mathrm{t}, J=7.4 \mathrm{~Hz}, 2 \mathrm{H}), 2.74-2.67\left(\mathrm{~m}, 3 \mathrm{H}, \mathrm{Ha}-1^{\prime}\right), 2.60-2.58(\mathrm{~m}, 3 \mathrm{H}, \mathrm{H}-5), 2.53-2-47(\mathrm{~m}, 3 \mathrm{H}$, $\left.\mathrm{Hb}-1^{\prime}\right), 2.28-2.24\left(\mathrm{~m}, 6 \mathrm{H}, \mathrm{SCOCH}_{3}, \mathrm{Hb}-1\right), 2.03\left(\mathrm{~s}, 9 \mathrm{H}, \mathrm{OCH}_{3}\right), 1.99\left(\mathrm{~s}, 18 \mathrm{H}, \mathrm{OCH}_{3}\right), 1.98$ (s, 9H, $\left.\mathrm{OCH}_{3}\right), 1.91-1.84\left(\mathrm{~m}, 6 \mathrm{H}, \mathrm{H}-5^{\prime}\right), 1.56-1.48(\mathrm{~m}, 4 \mathrm{H}), 1.33-1.22(\mathrm{~m}, 32 \mathrm{H}) \mathrm{ppm} ;{ }^{13} \mathrm{C}-$ $\operatorname{NMR}\left(50 \mathrm{MHz}, \mathrm{CDCl}_{3}\right): \delta=196.0\left(\mathrm{SCOCH}_{3}\right), 170.9-169.7\left(12 \mathrm{C}, \mathrm{OCOCH}_{3}\right), 169.7(\mathrm{CONH})$, 144.9 (3C, triazole), 122.6 (3C, triazole), 74.8 (3C, C-2), 71.6-70.1 (8C), 69.6 (3C, C-4), 69.5 (3C, C-3), 68.9 (3C, C-8'), 65.1 (3C, C-7'), 61.8 (3C, C-5), $59.6\left(4 \mathrm{C}, \mathrm{C}-6, \mathrm{NHC}\left(\mathrm{CH}_{2} \mathrm{O}-\right)_{3}\right), 53.0(3 \mathrm{C}$, $\mathrm{C}-1), 51.6\left(3 \mathrm{C}, \mathrm{C}-1^{\prime}\right), 50.2\left(3 \mathrm{C}, \mathrm{C}-6^{\prime}\right), 30.4\left(\mathrm{CH}_{2} \mathrm{SCOCH}_{3}\right), 29.6-25.0(22 \mathrm{C}), 20.9,20.7(12 \mathrm{C}$, $\left.\mathrm{COCH}_{3}\right)$ ppm; MS (ESI): $m / z$ 1033.92 (100, $\left.(m / z)+2 \mathrm{Na}^{+}\right)$; IR (CDCl3): $\tilde{v}=3022,2932,2858$, $1744,1675,1525,1369,1220,1098,1032 \mathrm{~cm}^{-1}$. Elemental analysis (\%) for $\mathrm{C}_{94} \mathrm{H}_{151} \mathrm{~N}_{13} \mathrm{O}_{33} \mathrm{~S}$ (2023.34): calcd C, 55.80; H, 7.52; N, 9.00; found: C, 55.76; H, 7.78; N, 8.22.

\subsubsection{General Procedure for the In Situ Preparation of Ligands $\mathbf{1 2}$ and $\mathbf{1 8}$}

To a solution of $\mathbf{1 1}$ or $\mathbf{1 7}$ in $\mathrm{CD}_{3} \mathrm{OD}(10 \mathrm{mg} / \mathrm{mL}), 30$ equivalents of NaOMe were added, and the reaction mixture was left stirring for $2 \mathrm{~h}$ at $25^{\circ} \mathrm{C}$ under nitrogen atmosphere. The complete disappearance of the starting material was attested via ${ }^{1} \mathrm{H} N \mathrm{NR}$, and the crude, containing compounds $\mathbf{1 2}$ or 18, respectively, was directly used for the preparation of AuGNPs. 


\subsubsection{General Procedure for the Preparation of AuGNPs 1-5}

An aqueous solution of $\mathrm{HAuCl}_{4}(25 \mathrm{mM}, 1$ equiv.) was added to a $12 \mathrm{mM}$ methanolic solution of a suitable mixture of thiol-ending monosaccharide and DNJ ligands (3 equiv. overall). An aqueous solution of $\mathrm{NaBH}_{4}(1 \mathrm{M}, 27$ equiv.) was then added in four portions, with vigorous shaking. The black suspension formed was shaken for $2 \mathrm{~h}$ at $25^{\circ} \mathrm{C}$. The residue was washed several times with $\mathrm{MeOH}$. In order to effectively separate the nanoparticles from the supernatant, centrifugation $(12,000 \mathrm{rpm}, 2 \mathrm{~min})$ was performed. The residue was dissolved in a minimal volume of HPLC gradient grade water and purified by dialysis (SnakeSkin ${ }^{\circledR}$ Pleated Dialysis Tubing, 10,000 MWCO and Slide-A-Lyzer ${ }^{\circledR} 10 \mathrm{~K}$ Dialysis Cassettes, 10,000 MWCO). DNJ-coated AuGNPs were obtained as a dark-brown powder after freeze-drying and characterized via ${ }^{1} \mathrm{H}$ NMR, UV-Vis spectroscopy and TEM analysis (see Supplementary Materials). For the analysis of the ratio between the active component (DNJ-based ligand) and the inner component (monosaccharide ligand), ${ }^{1} \mathrm{H}$ NMR spectra of the initial mixture and the supernatant, after AuGNP formation, were recorded. The DNJ loading on the AuGNPs was evaluated by quantitative NMR (qNMR) using 3-(trimethylsilyl)propionic-2,2,3,3- $d_{4}$ acid, sodium salt (TSP- $\left.\mathrm{d}_{4}\right)$ as an internal standard in the $\mathrm{D}_{2} \mathrm{O}$ solution of the AuGNPs. The prepared AuGNPs can be stored at $4{ }^{\circ} \mathrm{C}$ for months while maintaining their biophysical properties.

\section{Preparation of $40 \%$ monoDNJ-Au- $\beta$ Glc 1}

A 1:1.5 mixture of thiol-ending $12(4.5 \mathrm{mg}, 2.65 \mu \mathrm{mol})$ and $\beta \mathrm{GlcC}_{5} \mathrm{SH} 13(1.1 \mathrm{mg}$, $3.89 \mu \mathrm{mol})$ in $\mathrm{CD}_{3} \mathrm{OD}(1.1 \mathrm{~mL})$ was used to obtain $0.35 \mathrm{mg}$ of AuGNP 1. TEM (average diameter): $1.8 \pm 0.4 \mathrm{~nm}$. Quantitative ${ }^{1} \mathrm{H}-\mathrm{NMR}\left(400 \mathrm{MHz}, \mathrm{D}_{2} \mathrm{O}\right.$ containing $0.05 \mathrm{wt} . \%$ of 3-(trimethylsilyl)propionic-2,2,3,3- $d_{4}$ acid, sodium salt as an internal standard): $0.15 \mathrm{mg}$ of 1 were dissolved in $200 \mu \mathrm{L}$ of $\mathrm{D}_{2} \mathrm{O}$ and $15 \mu \mathrm{L}$ of $\mathrm{D}_{2} \mathrm{O}$, containing $0.05 \mathrm{wt} . \%$ TSP, were added and 31 nmoles of DNJ conjugate were found. In the quantitative NMR (qNMR) a mediated value of the multiplet corresponding to Ha- $1^{\prime}$ proton signal $(\delta=2.84 \mathrm{ppm}, 1 \mathrm{H})$ of DNJ conjugate and the multiplet corresponding to $\mathrm{H}-6(\delta=2.60-2.45 \mathrm{ppm}, 2 \mathrm{H})$ was selected for integration as it falls in a spectral region free of other signals. UV-Vis $\left(\mathrm{H}_{2} \mathrm{O}, 0.1 \mathrm{mg} / \mathrm{mL}\right)$ : absence of a maximum band at around $520 \mathrm{~nm}$.

Preparation of $40 \%$ monoDNJ-Au- $\alpha$ Man 2

A 1:1.5 mixture of thiol-ending $12(3.8 \mathrm{mg}, 5.89 \mu \mathrm{mol})$ and $\alpha \mathrm{ManC}_{5} \mathrm{SH} 14(2.5 \mathrm{mg}$, $8.84 \mu \mathrm{mol})$ in $\mathrm{CD}_{3} \mathrm{OD}(1.2 \mathrm{~mL})$ was used to obtain $1.33 \mathrm{mg}$ of AuGNPs 2. TEM (average diameter): $2.1 \pm 0.6 \mathrm{~nm}$. Quantitative ${ }^{1} \mathrm{H}-\mathrm{NMR}\left(400 \mathrm{MHz}, \mathrm{D}_{2} \mathrm{O}\right.$ containing $0.05 \mathrm{wt} . \%$ of 3-(trimethylsilyl)propionic-2,2,3,3- $d_{4}$ acid, sodium salt as an internal standard): $0.60 \mathrm{mg}$ of 2 were dissolved in $200 \mu \mathrm{L}$ of $\mathrm{D}_{2} \mathrm{O}$ and $40 \mu \mathrm{L}$ of $\mathrm{D}_{2} \mathrm{O}$ containing $0.05 \mathrm{wt} . \%$ TSP were added and 140 nmoles of DNJ conjugate were found. Significant peaks: $\delta=2.85-2.95$ (br signal, $1 \mathrm{H}$, from DNJ conjugate) ppm. UV-Vis $\left(\mathrm{H}_{2} \mathrm{O}, 0.1 \mathrm{mg} / \mathrm{mL}\right)$ : absence of a maximum band at around $520 \mathrm{~nm}$.

\section{Preparation of $20 \%$ trisDNJ-Au- $\beta$ Glc 3}

A 1:4 mixture of thiol-ending $18(10.9 \mathrm{mg}, 7.41 \mu \mathrm{mol})$ and $\beta \mathrm{Glc}_{5} \mathrm{SH} 13(8.4 \mathrm{mg}$, $29.64 \mu \mathrm{mol}$ ) in $\mathrm{CD}_{3} \mathrm{OD}(3.1 \mathrm{~mL}$ ) was used to obtain $4.5 \mathrm{mg}$ of AuGNPs 3. TEM (average diameter): $2.1 \pm 0.5 \mathrm{~nm}$. Quantitative ${ }^{1} \mathrm{H}-\mathrm{NMR}\left(400 \mathrm{MHz}, \mathrm{D}_{2} \mathrm{O}\right.$ containing $0.05 \mathrm{wt} . \%$ of 3-(trimethylsilyl)propionic-2,2,3,3- $d_{4}$ acid, sodium salt as an internal standard): $0.60 \mathrm{mg}$ of 3 were dissolved in $180 \mu \mathrm{L}$ of $\mathrm{D}_{2} \mathrm{O}$ and $40 \mu \mathrm{L}$ of $\mathrm{D}_{2} \mathrm{O}$ containing $0.05 \mathrm{wt} . \%$ TSP were added and 170 nmoles of DNJ conjugate were found. Significant peaks: $\delta=7.83(\mathrm{br} \mathrm{s}, 3 \mathrm{H}$, triazole from DNJ derivative) ppm. UV-Vis $\left(\mathrm{H}_{2} \mathrm{O}, 0.1 \mathrm{mg} / \mathrm{mL}\right)$ : absence of a maximum band at around $520 \mathrm{~nm}$.

\section{Preparation of $20 \%$ trisDNJ-Au- $\alpha$ Man 4}

A 1:4 mixture of thiol-ending $18(10.9 \mathrm{mg}, 7.41 \mu \mathrm{mol})$ and $\alpha \mathrm{ManC}_{5} \mathrm{SH} 14(8.3 \mathrm{mg}$, $29.64 \mu \mathrm{mol})$ in $\mathrm{CD}_{3} \mathrm{OD}(3.1 \mathrm{~mL})$ was used to obtain $3.7 \mathrm{mg}$ of AuGNP 4. TEM (average 
diameter): $2.0 \pm 0.4 \mathrm{~nm}$. Quantitative ${ }^{1} \mathrm{H}-\mathrm{NMR}\left(400 \mathrm{MHz}, \mathrm{D}_{2} \mathrm{O}\right.$ containing $0.05 \mathrm{wt} . \%$ of 3-(trimethylsilyl)propionic-2,2,3,3- $d_{4}$ acid, sodium salt as an internal standard): $0.60 \mathrm{mg}$ of 4 were dissolved in $180 \mu \mathrm{L}$ of $\mathrm{D}_{2} \mathrm{O}$ and $40 \mu \mathrm{L}$ of $\mathrm{D}_{2} \mathrm{O}$ containing 0.05 wt.\% TSP were added and 135 nmoles of DNJ conjugate were found. Significant peaks: $\delta=7.84$ (br s, 3H, triazole from DNJ derivative) ppm. UV-Vis $\left(\mathrm{H}_{2} \mathrm{O}, 0.1 \mathrm{mg} / \mathrm{mL}\right)$ : absence of a maximum band at around $520 \mathrm{~nm}$.

\section{Preparation of $40 \%$ trisDNJ-Au- $\alpha$ Man 5}

A 1:1.8 mixture of thiol-ending $18(6.9 \mathrm{mg}, 4.70 \mu \mathrm{mol})$ and $\alpha \mathrm{ManC}_{5} \mathrm{SH} 14(2.4 \mathrm{mg}$, $8.37 \mu \mathrm{mol})$ in $\mathrm{CD}_{3} \mathrm{OD}(0.97 \mathrm{~mL})$ was used to obtain $1.7 \mathrm{mg}$ of AuGNP 5. TEM (average diameter): $2.1 \pm 0.5 \mathrm{~nm}$. Quantitative ${ }^{1} \mathrm{H}-\mathrm{NMR}\left(400 \mathrm{MHz}, \mathrm{D}_{2} \mathrm{O}\right.$ containing $0.05 \mathrm{wt} \%$ of 3-(trimethylsilyl)propionic-2,2,3,3- $d_{4}$ acid, sodium salt as an internal standard): $0.60 \mathrm{mg}$ of 5 were dissolved in $180 \mu \mathrm{L}$ of $\mathrm{D}_{2} \mathrm{O}$ and $40 \mu \mathrm{L}$ of $\mathrm{D}_{2} \mathrm{O}$ containing 0.05 wt.\% TSP were added and 151 nmoles of DNJ conjugate were found. Significant peaks: $\delta=7.81$ (br s, $3 \mathrm{H}$, triazole from DNJ derivative), 2.57-2.44 (m, 6H, from DNJ conjugate) ppm. UV-Vis $\left(\mathrm{H}_{2} \mathrm{O}\right.$, $0.1 \mathrm{mg} / \mathrm{mL}$ ): absence of a maximum band at around $520 \mathrm{~nm}$.

\subsection{Biological Evaluation}

$p$-Nitrophenyl- $\alpha$-D-mannopyranoside and $\alpha$-mannosidase (EC 3.2.1.24, from Jack Bean, $\mathrm{Km}=2.0 \mathrm{mM}$ pH 5.5) were purchased from Merck (Darmstadt, Germany). Inhibition constants were determined by spectrophotometrically measuring the residual hydrolytic activities of the mannosidase against $p$-nitrophenyl- $\alpha$-D-mannopyranoside in the presence and absence of the inhibitor with a VersaMax Microplate Reader. All kinetics were performed at $25^{\circ} \mathrm{C}$ and started by substrate addition $(20 \mu \mathrm{L})$ in a $100 \mu \mathrm{L}$ assay medium (acetate buffer, $0.2 \mathrm{M}, \mathrm{pH}=5)$ containing $\alpha$-mannosidase $(0.015 \mathrm{U} / \mathrm{mL})$, in presence or absence of various concentrations of inhibitor and substrate (concentrations from $\mathrm{km} / 8$ to $2 \mathrm{~km}$ ). After 15-30 min incubation, the reaction was quenched by the addition of $1 \mathrm{M} \mathrm{Na}_{2} \mathrm{CO}_{3}$ $100 \mu \mathrm{L})$. The absorbance of the resulting solution was determined at $405 \mathrm{~nm}$. Under these conditions, the $p$-nitrophenolate released led to optical densities linear with both reaction time and concentration of the enzyme. $K_{i}$ values were determined, in duplicate or triplicate, using the Dixon or Lineweaver-Burk graphical methods with Microsoft Excel [37].

\section{Conclusions}

In conclusion, we report, in this work, the first example of gold nanoparticles decorated with the iminosugar deoxynojirimycin (DNJ). Jack bean $\alpha$-mannosidase (JB $\alpha$-man) was chosen as the target enzyme for the biological evaluation due to its well-known responsiveness to the multivalent presentation of iminosugar inhitopes. Monovalent and trivalent DNJ-derivative functionalized with a thiol were synthesized and used in mixture with a glucose or mannose thiol-ending inner component for the in-situ preparation of heterovalent AuGNPs. AuGNPs, bearing only the sugar component, were also prepared as control systems. Biological assays towards $\mathrm{JB} \alpha$-man revealed a competitive inhibition for the whole set of AuGNPs 1-5, while glyco-coated AuGNPs 6-7 were inactive, thus demonstrating the fundamental role played by the iminosugar moiety for the inhibition. Comparison with the monovalent reference 19 highlighted affinity enhancements, per inhitope higher than 1600, for the AuGNPs 3-5 decorated with the trivalent DNJ-derivative, with the best result obtained for AuGNP $5\left(K_{i}=84 \mathrm{nM}, r p n=3833\right)$. Interestingly, AuGNPs 2 and 5 share similar concentration in DNJ but vary by their local inhitope density, which makes them powerful tools to measure the impact of DNJ distribution onto the affinity enhancements. The significant gain of affinity, observed between the DNJ-coated and DNJ dendron-coated AuGNPs, highlights the importance of the bind-and-recapture effect in the complex, interconnected mechanisms underlying the inhibitory multivalent effects. Further investigation with these new nanosystems is currently ongoing in our laboratories. 
Supplementary Materials: The following are available online. The ${ }^{1} \mathrm{H}$ and ${ }^{13} \mathrm{C}-\mathrm{NMR}$ spectra of DNJbased ligands 9, 11, 16 and 17; the characterization of AuGNPs 1-5 $\left({ }^{1} \mathrm{H}-\mathrm{NMR}\right.$ spectra, TEM graphs, UV-Vis spectra); the Dixon and Lineweaver-Burk plots for determination of inhibition constants of AuGNPs 1-5; Table S1 which contains a resume of DNJ-based AuGNPs 1-5 characterization (average size diameter, calculated amount of iminosugar).

Author Contributions: C.M., F.C. and A.G. planned the synthetic strategy and wrote the manuscript; M.M., M.d.1.A.R. and S.M. characterized the nanosystems; C.V. and J.P.S. made the syntheses; A.B. performed the biological tests, interpreted the results and analyzed them with P.C.; P.C. raised funds. All authors contributed to the writing of the manuscript. All authors have read and agreed to the published version of the manuscript.

Funding: MIUR-Italy ("Progetto Dipartimenti di Eccellenza 2018-2022") allocated to the Department of Chemistry "Ugo Schiff”, Università di Firenze and Regione Toscana (Bando Salute 2018) for the project: "Late onset Lysosomal Storage Disorders (LSDs) in the differential diagnosis of neurodegenerative diseases: development of new diagnostic procedures and focus on potential pharma-cological chaperones (PCs), Acronym: Lysolate). This work was also funded by the CNRS (UMR 7509), the University of Strasbourg and the Fondation pour la Recherche en Chimie (icFRC Strasbourg).

Acknowledgments: We thank Patrizia Andreozzi for fruitful discussion on experimental data.

Conflicts of Interest: The authors declare no conflict of interest.

Sample Availability: Samples of the compounds reported in the manuscript are not available from the authors.

\section{References}

1. Diot, J.; García-Moreno, M.I.; Gouin, S.G.; Ortiz Mellet, C.; Haupt, K.; Kovensky, J. Multivalent iminosugars to modulate affinity and selectivity for glycosidases. Org. Biomol. Chem. 2009, 7, 357-363. [CrossRef]

2. Compain, P.; Decroocq, C.; Iehl, J.; Holler, M.; Hazelard, D.; Mena Barragán, T.; Ortiz Mellet, C.; Nierengarten, J.-F. Glycosidase Inhibition with Fullerene Iminosugar Balls: A Dramatic Multivalent Effect. Angew. Chem. Int. Ed. 2010, 49, 5753-5756. [CrossRef] [PubMed]

3. Compain, P.; Bodlenner, A. The multivalent effect in glycosidase inhibition: A new, rapidly emerging topic in glycoscience. ChemBioChem 2014, 15, 1239-1251. [CrossRef] [PubMed]

4. Gouin, S.G. Multivalent inhibitors for carbohydrate-processing enzymes: Beyond the "lock-and-key" concept. Chem. Eur. J. 2014, 20, 11616-11628. [CrossRef] [PubMed]

5. Zelli, R.; Longevial, J.-F.; Dumy, P.; Marra, A. Synthesis and biological properties of multivalent iminosugars. New J. Chem. 2015, 30, 5050-5074. [CrossRef]

6. Kanfar, N.; Bartolami, E.; Zelli, R.; Marra, A.; Winum, J.-Y.; Ulrich, S.; Dumy, P. Emerging trends in enzyme inhibition by multivalent nanoconstructs. Org. Biomol. Chem. 2015, 13, 9894-9906. [CrossRef]

7. Matassini, C.; Parmeggiani, C.; Cardona, F.; Goti, A. Are enzymes sensitive to the multivalent effect? Emerging evidence with glycosidases. Tetrahedron Lett. 2016, 57, 5407-5415. [CrossRef]

8. Compain, P. Multivalent effect in glycosidase inhibition: The end of the beginning. Chem. Rec. 2020, 20, 10-22. [CrossRef]

9. González-Cuesta, M.; Ortiz Mellet, C.; García Fernández, J.M. Carbohydrate supramolecular chemistry: Beyond the multivalent effect. Chem. Commun. 2020, 56, 5207-5222. [CrossRef]

10. Lepage, M.L.; Schneider, J.P.; Bodlenner, A.; Meli, A.; De Riccardis, F.; Schmitt, M.; Tarnus, C.; Nguyen-Huynh, N.-T.; Francois, Y.-N.; Leize-Wagner, E.; et al. Iminosugar-Cyclopeptoid Conjugates Raise Multivalent Effect in Glycosidase Inhibition at Unprecedented High Levels. Chem. Eur. J. 2016, 22, 5151-5155. [CrossRef]

11. Howard, E.; Cousido-Siah, A.; Lepage, M.L.; Schneider, J.P.; Bodlenner, A.; Mitschler, A.; Meli, A.; Izzo, I.; Alvarez, A.; Podjarny, A.; et al. Structural Basis of Outstanding Multivalent Effects in Jack Bean $\alpha$-Mannosidase Inhibition. Angew. Chem. Int. Ed. 2018, 57, 8002-8006. [CrossRef]

12. Mirabella, S.; D’Adamio, G.; Matassini, C.; Goti, A.; Delgado, S.; Gimeno, A.; Robina, I.; Moreno-Vargas, A.J.; Šesták, S.; JiménezBarbero, J.; et al. Mechanistic Insight into the Binding of Multivalent Pyrrolidines to $\alpha$-Mannosidases. Chem. Eur. J. 2017, 23, 14585-14596. [CrossRef] [PubMed]

13. Abellán Flos, M.; García Moreno, M.I.; Ortiz Mellet, C.; García Fernández, J.M.; Nierengarten, J.-F.; Vincent, S.P. Potent Glycosidase Inhibition with Heterovalent Full-erenes: Unveiling the Binding Modes Triggering Multivalent Inhibition. Chem. Eur. J. 2016, 22, 11450-11460. [CrossRef] [PubMed]

14. Siriwardena, A.; Khanal, M.; Barras, A.; Bande, O.; Mena-Barragán, T.; Ortiz Mellet, C.; García Fernández, J.M.; Boukherroub, R.; Szunerits, S. Unprecedented Inhibition of Glyco-sidase-Catalyzed Substrate Hydrolysis by Nanodiamond-Grafted O-Glycosides. RSC Adv. 2015, 5, 100568-100578. [CrossRef] 
15. Alali, U.; Vallin, A.; Bil, A.; Khanchouche, T.; Mathiron, D.; Przybylski, C.; Beaulieu, R.; Kovensky, J.; Benazza, M.; Bonnet, V. The Uncommon Strong Inhibition of $\alpha$-Glucosidase by Multivalent Glycoclusters Based on Cyclodextrin Scaffolds. Org. Biomol. Chem. 2019, 17, 7228-7237. [CrossRef]

16. Marradi, M.; Chiodo, F.; García, I.; Penadés, S. Glyconanoparticles as multifunctional and multimodal carbohydrate systems. Chem. Soc. Rev. 2013, 42, 4728-4745. [CrossRef]

17. Marradi, M.; García, I.; Penadés, S. Carbohydrate-based nanoparticles for potential applications in medicine. In Nanoparticles in Translational Science and Medicine; Villaverde, A., Ed.; Elsevier: Amsterdam, The Netherlands, 2011; Volume 104, pp. 141-173, ISBN 9780124160200.

18. Alvarez-Dorta, D.; Brissonnet, Y.; Saumonneau, A.; Deniaud, D.; Bernard, J.; Yan, X.; Tellier, C.; Daligault, F.; Gouin, S.G. Magnetic Nanoparticles Coated with Thiomannosides or Iminosugars to Switch and Recycle Galactosidase Activity. ChemistrySelect 2017, 2, 9552-9556. [CrossRef]

19. Kleps, I.; Ignat, T.; Miu, M.; Craciunoiu, F.; Trif, M.; Simion, M.; Bragaru, A.; Dinescu, A. Nanostructured Silicon Particles for Medical Applications. J. Nanosci. Nanotechnol. 2010, 10, 2694-2700. [CrossRef]

20. Bonduelle, C.; Huang, J.; Mena-Barragán, T.; Ortiz Mellet, C.; Decroocq, C.; Etamé, E.; Heise, A.; Compain, P.; Lecommandoux, S. Iminosugar-based glycopolypeptides: Glycosidase inhibition with bioinspired glycoprotein analogue micellar self-assemblies. Chem. Commun. 2014, 50, 3350-3352. [CrossRef] [PubMed]

21. Matassini, C.; Marradi, M.; Cardona, F.; Parmeggiani, C.; Robina, I.; Moreno-Vargas, A.J.; Penadés, S.; Goti, A. Gold nanoparticles are suitable cores for building tunable iminosugar multivalency. RSC Adv. 2015, 5, 95817-95822. [CrossRef]

22. Matassini, C.; Vanni, C.; Goti, A.; Morrone, A.; Marradi, M.; Cardona, F. Multimerization of DAB-1 onto Au GNPs affords new potent and selective N-acetylgalactosamine-6-sulfatase (GALNS) inhibitors. Org. Biomol. Chem. 2018, 16, 8604-8612. [CrossRef]

23. Joosten, A.; Schneider, J.P.; Lepage, M.L.; Tarnus, C.; Bodlenner, A.; Compain, P. A Convergent Strategy for the Synthesis of Second-Generation Iminosugar Clusters Using “Clickable” Trivalent Dendrons. Eur. J. Org. Chem. 2014, 1866-1872. [CrossRef]

24. Schneider, J.P.; Tommasone, S.; Della Sala, P.; Gaeta, C.; Talotta, C.; Tarnus, C.; Neri, P.; Bodlenner, A.; Compain, P. Synthesis and Glycosidase Inhibition Properties of Ca-lix[8]Arene-Based Iminosugar Click Clusters. Pharmaceuticals 2020, 13, 366-386. [CrossRef] [PubMed]

25. Martínez-Ávila, O.; Hijazi, K.; Marradi, M.; Clavel, C.; Campion, C.; Kelly, C.; Penadés, S. Gold Manno-Glyconanoparticles: Multivalent Systems to Block HIV-1 gp120 Binding to the Lectin DC-SIGN. Chem. Eur. J. 2009, 15, 9874-9888. [CrossRef]

26. Decroocq, C.; Rodríguez-Lucena, D.; Russo, V.; Mena Barragán, T.; Ortiz Mellet, C.; Compain, P. The Multivalent Effect in Glycosidase Inhibition: Probing the Influence of Architectural Parameters with Cyclodextrin-based Iminosugar Click Clusters. Chem. Eur. J. 2011, 17, 13825-13831. [CrossRef]

27. Ayesa, S.; Samuelsson, B.; Classon, B. A One-Pot, Solid-Phase Synthesis of Secondary Amines from Reactive Alkyl Halides and an Alkyl Azide. Synlett 2008, 97-99.

28. Chabre, Y.M.; Contino-Pépin, C.; Placide, V.; Shiao, T.C.; Roy, R. Expeditive synthesis of glycodendrimer scaffolds based on versatile TRIS and mannoside derivatives. J. Org. Chem. 2008, 73, 5602-5605. [CrossRef]

29. Kolb, H.C.; Finn, M.G.; Sharpless, K.B. Click Chemistry: Diverse Chemical Function from a Few Good Reactions. Angew. Chem. Int. Ed. 2001, 40, 2004-2021. [CrossRef]

30. Rostovtsev, V.C.; Green, L.G.; Fokin, V.V.; Sharpless, K.B. A Stepwise Huisgen Cycloaddition Process: Copper(I)-Catalyzed Regioselective Ligation of Azides and Terminal Alkynes. Angew. Chem. Int. Ed. 2002, 41, 2596-2599. [CrossRef]

31. Tornøe, C.W.; Christensen, C.; Meldal, M. Peptidotriazoles on Solid Phase: [1,2,3]-Triazoles by Regiospecific Copper(I)-Catalyzed 1,3-Dipolar Cycloadditions of Terminal Alkynes to Azides. J. Org. Chem. 2002, 67, 3057-3064. [CrossRef]

32. Manea, F.; Bindoli, C.; Fallarini, S.; Lombardi, G.; Polito, L.; Lay, L.; Bonomi, R.; Mancin, F.; Scrimin, P. Multivalent, SaccharideFunctionalized Gold Nanoparticles as Fully Synthetic Analogs of Type A Neisseria meningitidis Antigens. Adv. Mater. 2008, 20, 4348-4352. [CrossRef]

33. Chiodo, F.; Enríquez-Navas, P.M.; Angulo, J.; Marradi, M.; Penadés, S. Assembling different antennas of the gp120 high mannosetype glycans on gold nanoparticles provides superior binding to the anti-HIV antibody $2 \mathrm{G} 12$ than the individual antennas. Carbohydr. Res. 2015, 405, 102-109. [CrossRef] [PubMed]

34. Hostetler, M.J.; Wingate, J.E.; Zhong, C.-J.; Harris, J.E.; Vachet, R.W.; Clark, M.R.; Londono, J.D.; Green, S.J.; Stokes, J.J.; Wignall, G.D.; et al. Alkanethiolate Gold Cluster Molecules with Core Diameters from 1.5 to $5.2 \mathrm{~nm}$ : Core and Monolayer Properties as a Function of Core Size. Langmuir 1998, 14, 17-30. [CrossRef]

35. Zhou, M.; Zeng, C.; Chen, Y.; Zhao, S.; Sfeir, M.Y.; Zhu, M.; Jin, R. Evolution from the plasmon to exciton state in ligand-protected atomically precise gold nanoparticles. Nat. Commun. 2016, 7, 13240. [CrossRef]

36. Decroocq, C.; Joosten, A.; Sergent, R.; Mena Barragan, T.; Ortiz Mellet, C.; Compain, P. The Multivalent Effect in Glycosidase Inhibition: Probingthe Influence of Valency, Peripheral Ligand Structure, and Topology with Cyclodextrin-Based Iminosugar ClickClusters. ChemBioChem 2013, 14, 2038-2049. [CrossRef] [PubMed]

37. Segel, I.H. Enzyme Kinetics: Behavior and Analysis of Rapid Equilibrium and Steady-State Enzyme Systems; John Wiley \& Sons: New York, NY, USA, 1975. 